S. Afr. J. Agric. Ext.

Vol. 46, No. 2, 2018: 107 - 118

Jacobs, Van Tol \&

DOI: http://dx.doi.org/10.17159/2413-3221/2018/v46n2a484

Du Preez.

\title{
FARMERS PERCEPTIONS OF PRECISION AGRICULTURE AND THE ROLE OF AGRICULTURAL EXTENSION: A CASE STUDY OF CROP FARMING IN THE SCHWEIZER-RENEKE REGION, SOUTH AFRICA
}

\author{
Jacobs, A. J. ${ }^{21}$, Van Tol, J. J., \& Du Preez, C. C. ${ }^{22}$ \\ Corresponding author: J. J. van Tol, Email: vantolij@ufs.ac.za
}

\begin{abstract}
The profit of crop production in South Africa is under pressure due to unreliable rainfall associated with climate change and severe competition in a highly subsidized global food market. Such constraints lead to food insecurity and could be dealt with by adopting inter alia precision agriculture. This study aimed to gain insights into crop farmers' perceptions of precision agriculture in the Schweizer-Reneke region. For this purpose, both qualitative and quantitative methods were applied by requesting 36 farmers to complete questionnaires; 18 who practice precision agriculture and 18 who do not. The results showed that economic considerations are the most important determinant whether precision agriculture is adopted or not by the crop farmers. Surprisingly, neither the age nor the education of farmers played a major role in the practicing or not of precision agriculture. Farmers who practice precision agriculture said that the most beneficial outcome is the costs saved through variable fertilizer application.
\end{abstract}

Keywords: Economic benefit, Fertilizer application, Food security, Management strategy, Sustainable agriculture

\section{INTRODUCTION}

The rapid population growth necessitates a $60 \%$ increase in production to ensure food security by 2050. In developed countries, additional agricultural land and water resources is scarce and the potential for expansion of agricultural activities is limited. In South Africa, only $13.7 \%$ of the total area is arable and used for intensive agriculture, mostly rain-fed. Crop production in South Africa is under pressure due to unreliable rainfall associated with climate change, higher input costs and low profits due to 'unfair' competition in a highly subsidized global market. To meet the food security challenges, producers need to intensify their production and make optimum use of available resources through practices such as precision agriculture (Nell, Maine \& Basson, 2006), whilst striving towards sustainability.

Precision agriculture can broadly be defined as a holistic and environmental friendly strategy whereby farmers can vary inputs and practices (spatially and temporally) using applicable technology and principles, for example the application of fertilizers, pesticides, cultivars, as well as cultivation and harvesting techniques (Pierce \& Nowak, 1999; Srinivasan, 2006). In practice, precision farming commences with the accumulation and consolidation of data at applicable scales, followed by interpretation and analysing the data, and lastly developing and implementation of management strategies for specific times and scales (National Research

\footnotetext{
${ }^{21}$ Department of Soil, Crop and Climate Sciences, University of the Free State, Bloemfontein 9300, South Africa. Email: bjacobs@humkoop.co.za

22 Email: dpreezcc@ufs.ac.za
} 
S. Afr. J. Agric. Ext.

Vol. 46, No. 2, 2018: 107 - 118

DOI: http://dx.doi.org/10.17159/2413-3221/2018/v46n2a484

Council, 1997). The overall aim of precision agriculture is to improve productivity while maintaining sustainability.

Sustainable agriculture, according to Smyth \& Dumanski (1995), lies on five pillars, namely 1. maintaining or improving production/services (productivity), 2. lowering of production risks (security), 3. protection of the quality and potential of natural resources and preventing soil and water degradation (protection), 4. economic feasibility and capability (viability), and 5. sociological appropriateness and adequacy (acceptability). According to the National Research Council (NRC, 1997), the advantages of precision agriculture include inter alia increased productivity, profitability, crop quality, environmental protection, quality of life, food security, and economic development. Hence, precision agriculture promotes sustainability.

The question is, however, with all the obvious and well documented advantages of precision agriculture, why is it not adopted by all farmers despite services offered by various agricultural suppliers like the mechanical and fertilizer industries? In this study, we therefore aim to gain insights into farmer's perceptions regarding precision agriculture in the Schweizer-Reneke area of South Africa. Some of these include the adoption and nature of precision farming, the costs associated with adoption of precision farming, the sustainability of precision farming, and suggestions to improve precision farming in the study area. Although this study area was fairly localised, we believe that the results can be extrapolated to similar environments (climates, management inputs, and production techniques) by well-trained extension service workers and some recommendations are also made in this regard.

\section{STUDY AREA AND METHODOLOGY}

\subsection{Site description}

The study area lies in the North West Province of South Africa, on the western side of the 'maize triangle' (Figure 1). Dryland maize is the dominant crop production activity with smaller areas under peanuts and sunflower.

The average annual rainfall is $507 \mathrm{~mm}$ (Table 1), with considerable inter seasonal variation. Based on 27 years of measured data (1990 to 2017), the lowest recorded annual rainfall was $266 \mathrm{~mm}$ (2012/13 season) and the highest was $858 \mathrm{~mm}$ in 2005/06 season (Agricultural Research Council - Institute for Soil, Climate and Water (ARC-ISCW), 2017). Average maximum temperatures are highest in January and December and the lowest average minimum temperatures are recorded in June and July. The area typically has 240 days without frost. 
S. Afr. J. Agric. Ext.

Vol. 46, No. 2, 2018: 107 - 118

DOI: http://dx.doi.org/10.17159/2413-3221/2018/v46n2a484

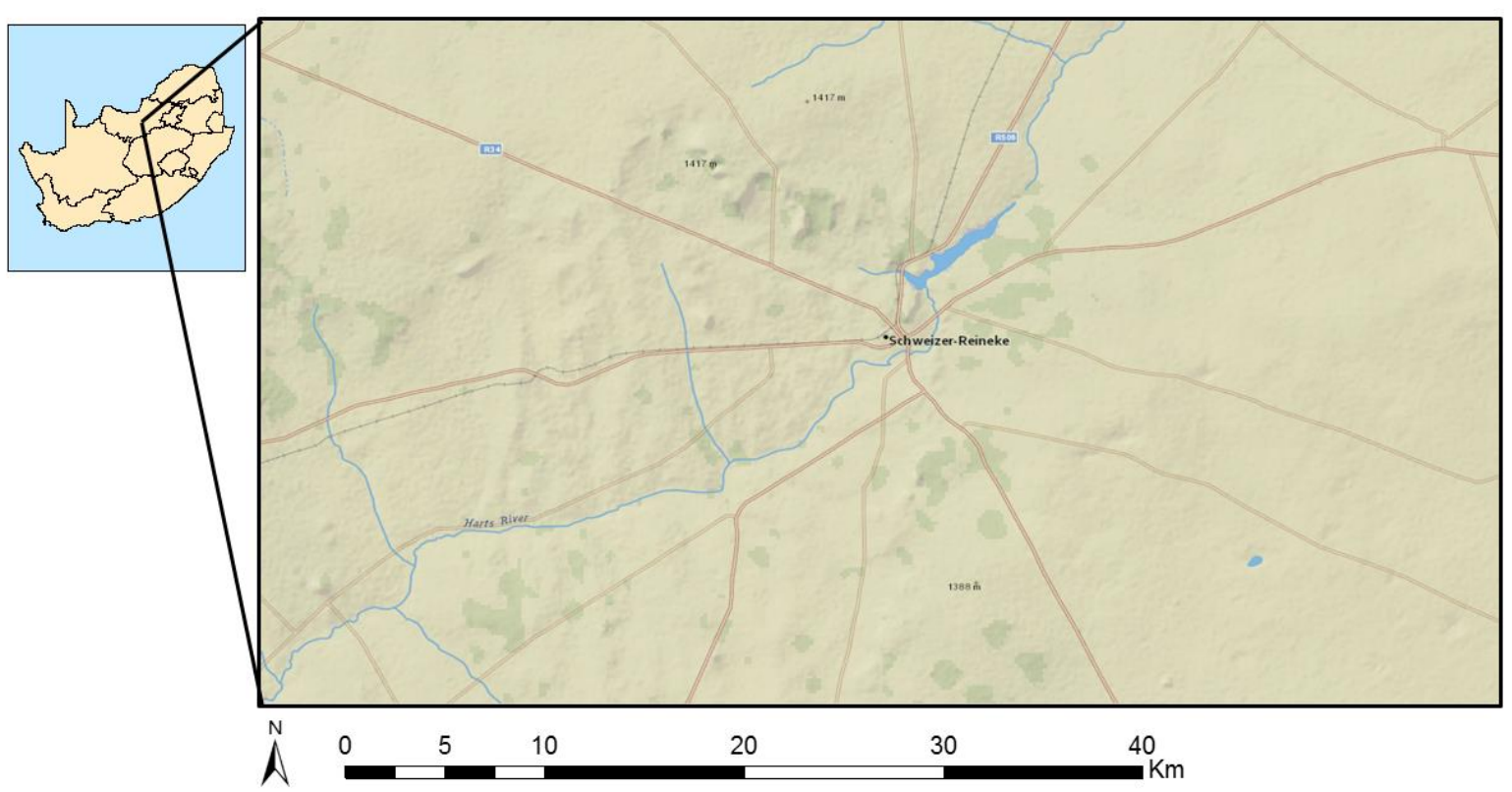

Figure 1: Location of the study area in the North West Province of South Africa.

Table 1: Long term climatic data for the Schweizer-Reneke area (ARC-ISCW, 2017)

\begin{tabular}{l|c|c|c|c|c|c|c|c|c|c|c|c}
\hline & Jan & Feb & Mar & Apr & May & Jun & Jul & Aug & Sep & Oct & Nov & Dec \\
\hline \hline Rainfall (mm) & 103 & 73 & 75 & 37 & 17 & 8 & 2 & 4 & 12 & 35 & 48 & 87 \\
\hline $\begin{array}{l}\text { Average maximum } \\
\text { temperature }\left({ }^{\circ} \mathrm{C}\right)\end{array}$ & 30 & 30 & 28 & 25 & 23 & 20 & 20 & 22 & 27 & 29 & 30 & 31 \\
\hline $\begin{array}{l}\text { Average minimum } \\
\text { temperature }\left({ }^{\circ} \mathrm{C}\right)\end{array}$ & 17 & 16 & 14 & 10 & 5 & 1 & 1 & 3 & 8 & 12 & 14 & 16 \\
\hline
\end{tabular}

Soils vary considerably between and within cultivated fields. The dominant soil forms in the area are Avalon, Clovelly, Pinedene, Bainsvlei, Hutton and Bloemdal forms (Soil Classification Working Group, 1991). Avalon and Bainsvlei soils can be described as PlinthicFerrasols, Clovelly and Hutton soils as Haplic-Ferrasols and Pinedene, and Bloemdal soils as Gleyic-Ferrasols according to the IUSS Working Group WRB (2014). Average clay contents are low and range between 5 to $20 \%$ and effective soil depth from $950 \mathrm{~mm}$ to deeper than 1 $500 \mathrm{~mm}$. The low clay contents and associated low cation exchange capacity (normally < 11 $\mathrm{cmol}_{\mathrm{c}} \cdot \mathrm{kg}^{-1}$ ) means that these soils are poorly buffered and sensitive to chemical degradation (Le Roux et al., 1999). Bierman (2001) studied the soil fertility status of soils in the North West Province. A summary of chemical analysis of 125 soil samples taken in cultivated fields in the Schweizer-Reneke area is presented in Table 2.

The drastic variation in almost all fertility indices is evident in Table 2. The $\mathrm{pH}$ ranged from acidic to neutral. Phosphorus $(\mathrm{P})$ and potassium $(\mathrm{K})$ range from low to very high. The average calcium $(\mathrm{Ca})$ and magnesium $(\mathrm{Mg})$ contents are below the optimum levels and the ratios between various cations vary considerably in the dataset. Table 2 suggest that even though the inherent properties of the soils are relatively homogenous, there are considerable variations in the application of fertilizers in the area. 
S. Afr. J. Agric. Ext.

Vol. 46, No. 2, 2018: 107 - 118

DOI: http://dx.doi.org/10.17159/2413-3221/2018/v46n2a484
Jacobs, Van Tol \&

Du Preez.

(License: CC BY 4.0)

Table 2: Summary of fertility status of soils $(n=125)$ in the Schweizer-Reneke area (Bierman, 2001)

\begin{tabular}{|c|c|c|c|c|c|}
\hline Parameter & Lowest & Highest & Mean & Median & $\begin{array}{l}\text { Optimum } \\
\text { levels }^{3}\end{array}$ \\
\hline $\mathrm{pH}(\mathrm{KCl})^{1}$ & 3.75 & 5.85 & 4.53 & 4.43 & $4.5-6.5$ \\
\hline $\mathrm{P}\left(\mathrm{mg} . \mathrm{kg}^{-1} ; \text { Bray1) }\right)^{1}$ & 8.00 & 67.00 & 27.80 & 25.00 & $15-25$ \\
\hline $\mathrm{K}\left(\mathrm{mg} \cdot \mathrm{kg}^{-1} ; \mathrm{NH}_{4} \mathrm{OA}_{\mathrm{c}}\right)^{1}$ & 32.00 & 318.00 & 145.10 & 142.00 & $80-160$ \\
\hline $\begin{array}{l}\mathrm{Ca}\left(\mathrm{mg} \cdot \mathrm{kg}^{-1}\right. \\
\left.\mathrm{NH}_{4} \mathrm{OA}_{\mathrm{c}}\right)^{1}\end{array}$ & 35.00 & 1198.00 & 297.70 & 280.00 & $300-600$ \\
\hline $\begin{array}{l}\mathrm{Mg} \mathrm{mg} \cdot \mathrm{kg}^{-1} \\
\left(\mathrm{NH}_{4} \mathrm{OA}_{\mathrm{c}}\right)^{1}\end{array}$ & 11.00 & 174.00 & 76.40 & 73.00 & $80-160$ \\
\hline $\mathrm{Ca} / \mathrm{Mg}$ ratio $^{2}$ & 0.30 & 16.99 & 2.40 & 2.30 & $1.5-4.5$ \\
\hline $\mathrm{Mg} / \mathrm{K}$ ratio $^{2}$ & 0.71 & 8.25 & 2.27 & 1.97 & $1.5-4.5$ \\
\hline$(\mathrm{Ca}+\mathrm{Mg}) / \mathrm{K}$ ratio $^{2}$ & 2.00 & 43.50 & 6.90 & 5.60 & $10-20$ \\
\hline
\end{tabular}

${ }^{1}$ Determined; ${ }^{2}$ Estimated; ${ }^{3}$ According to FSSA Fertilizer Handbook (2007).

\subsection{Research method and population}

This study included both quantitative and qualitative methods to address the research questions. The quantitative investigation involved identifying characteristics of an observed occurrence or the discovery of relationships and similarities between two or more occurrences. A causeand-effect result can also be identified based on answers to specific questions. The data can then be interpreted with the help of statistical analysis (Leedy \& Ormand, 2005). The foundation of the qualitative investigation was to accept that there is not necessarily a single and isolated 'truth' which must be discovered. Different perspectives of different individuals therefore have similar and equal 'truth' (Leedy \& Ormand, 2005). A combination of quantitative and qualitative methods complements one another (Zhang, 2001) and this was used in this study.

Questionnaires were provided to 36 farmers (18 who practice precision agriculture and 18 who do not). The aim of the study was explained, and anonymity was promised to all the farmers. Qualitative questions, requiring short explanations of the answers, were mixed with quantitative questions, which were in the majority. Feedback was received from all 36 farmers. The 36 farmers cultivated a total area of approximately 75000 ha (56 300 ha under precision farming and the remainder not).

\section{RESULTS AND DISCUSSION}

\subsection{Adoption and nature of precision agriculture systems}

In general, it is considered that older farmers are less likely to adopt new technology. For example, previous studies conducted in South Africa, such as Helm (2005) and Matela (2002), found that farmers older than 45 years are less likely to accept new technology when compared to farmers of between 35 and 45 years of age. In our study, there were no differences in the likelihood to adopt precision agriculture between age groups of 31-35, 41-45 and 51-55. Young farmers (26-50) and farmers between 46 and 50 are more likely to adopt precision agricultural practices whereas farmers older than 56 who appear to be unwilling to adopt the new technology (Figure 2a). 
S. Afr. J. Agric. Ext.

Vol. 46, No. 2, 2018: $107-118$

DOI: http://dx.doi.org/10.17159/2413-3221/2018/v46n2a484
Jacobs, Van Tol \&

Du Preez.

(License: CC BY 4.0)

According to Helm (2005) and Matela (2002), farmers with tertiary qualifications are more likely to adopt new technology. Interestingly, in our study, farmers with a first tertiary degree were by far less likely to adopt precision agriculture (Figure 2b). Farmers with a Matric Certificate, Diploma or master's Degrees were more likely to adopt precision agriculture. There was no difference in the likelihood of adoption of farmers with Honours degrees.

The size of the farm appeared to play an important role in the adoption of precision agriculture. Farmers cultivating less than 500 ha did not adopt precision agriculture and in general there was a considerable lack of adoption of cultivation area smaller than 1500 ha (Figure 2c). All the farmers cultivating areas larger than 3000 ha practice precision agriculture. Furthermore, these findings were conflicting existing theories that farm size does not influence adoption of precision agriculture (Helm, 2005; Matela, 2002).
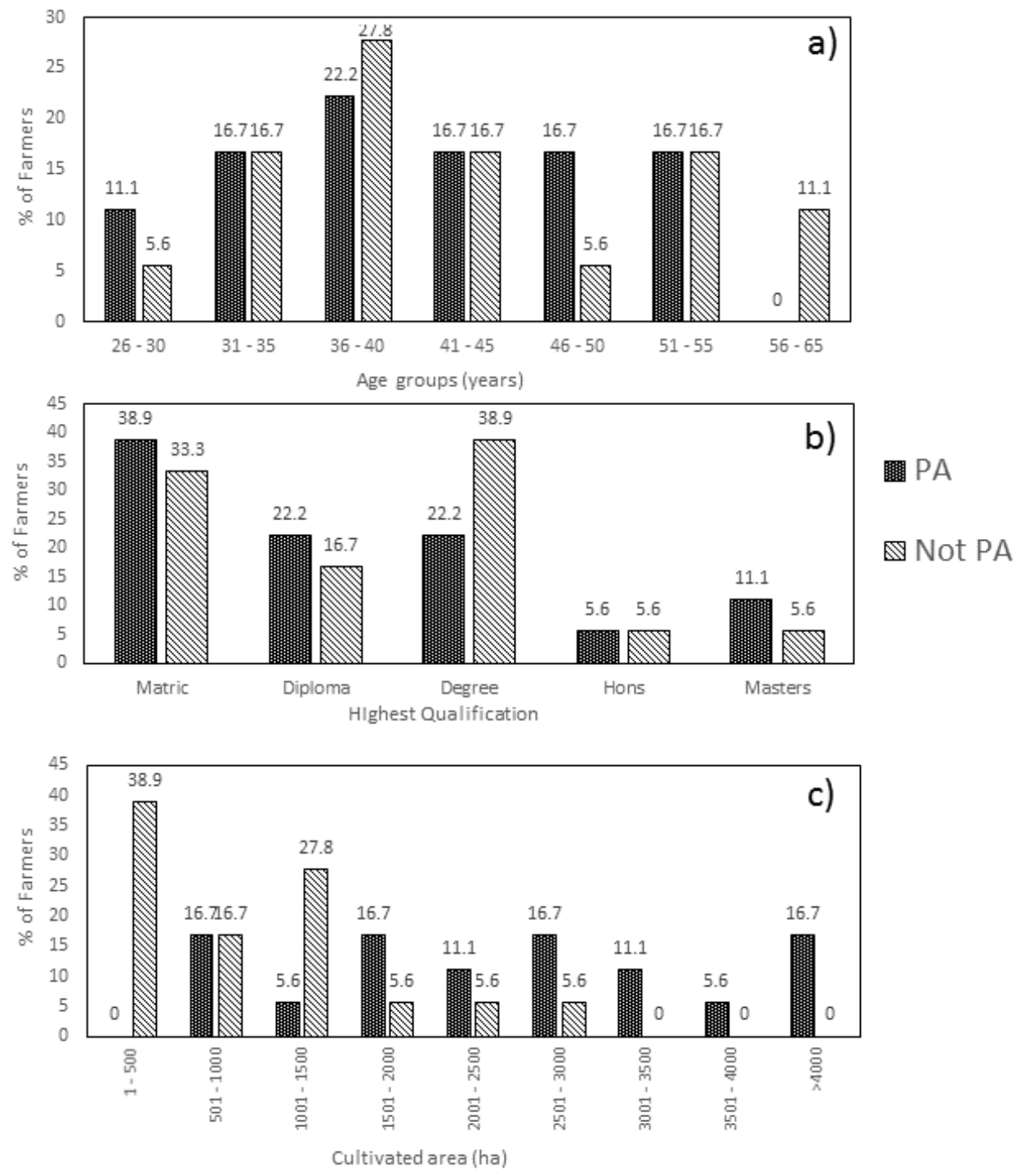

Figure 2: Impact of age (a), qualification (b), and cultivated area (c) on adoption of precision agriculture (PA - refers to farmers who practice precision agriculture and Not PA refers to farmers who are not practicing precision agriculture).

Partnerships may be a reason for not adopting precision agriculture technology. In this study, $22 \%$ of the farmers who are not practising precision agriculture are in a partnership, often with a father older than 56 years who still has the final say on management of the farm. 
S. Afr. J. Agric. Ext.

Vol. 46, No. 2, 2018: 107 - 118

DOI: http://dx.doi.org/10.17159/2413-3221/2018/v46n2a484
Jacobs, Van Tol \&

Du Preez.

(License: CC BY 4.0)

Most of the farmers have been practicing precision agriculture for longer than 4 years (Figure 3a). The majority of the farmers apply precision agriculture techniques through varying chemical amendments to the soils (Figure 3b). This includes varying application rates of lime, nitrogen $(\mathrm{N})$, phosphorus $(\mathrm{P})$, and potassium $(\mathrm{K})$. Economic benefits of varying application rates of these chemicals are widely documented (Babcock \& Pautsch, 1998; Godwin et al., 2002; Kahabka, Van Els, McClenahan \& Cox, 2004; Parkhomenko, Robert, Rogasik \& Schnug, 1999) and considered to be the dominant reason for adopting this approach. Nitrogen $(\mathrm{N})$ application rates are based on the estimated yield potential and hence the amount of $\mathrm{N}$ required to achieve this yield. Variation in yield potential in a specific field is determined by inherent soil properties (e.g. depth and nature of underlying material). One third to half of the required $\mathrm{N}$ is applied at planting and remaining applied as side or top dressing depending on the rainfall.
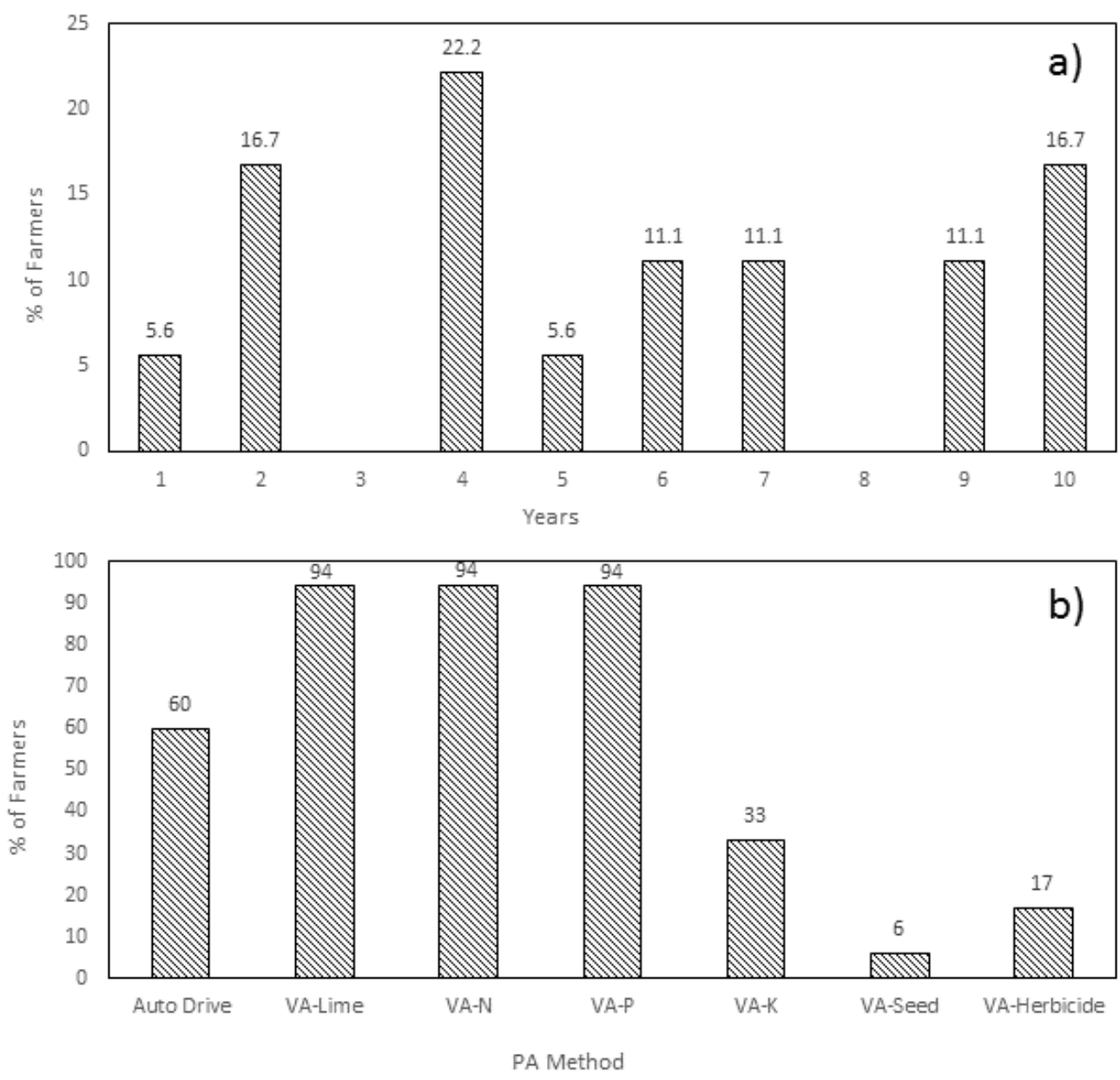

Figure 3: Number of years that precision agriculture is practiced by farmers (a) and different methods of practicing precision agriculture (b); VA - varying application of nitrogen $(\mathrm{N})$, phosphorus $(\mathrm{P})$ and potassium respectively $(\mathrm{K})$.

In South Africa, natural P contents of soils are low (Table 2) and applications are essential. Amendments of $\mathrm{P}$ are however expensive and recommended application rates are typically based on soil analysis with the aim to build the P content to optimum levels. To avoid rapid fixation in sesquioxide rich soils band-placing of $\mathrm{P}$ are normally conducted. Precision 
S. Afr. J. Agric. Ext.

Vol. 46, No. 2, 2018: 107 - 118

DOI: http://dx.doi.org/10.17159/2413-3221/2018/v46n2a484

management of $\mathrm{P}$ often yield economic and agronomic benefits (Clay, Malo, Reese \& Carlson, 2003).

Varying application rates of $\mathrm{K}$ seldom justify the spatial management costs (Maine, 2006). Soils in South Africa are seldom deficient in K (Table 2). It was therefore not surprising that only $33 \%$ of the farmers adopted the varying application of K. Long periods of crop production however lead to $\mathrm{K}$ deficiencies in some soils in South African (see minimum values in Table 2 for example). Spatial management of $\mathrm{K}$ therefore might become important in the near future. Only $6 \%$ of the farmers apply seed differentially. According to the farmers, the current cultivars (maize) are very adjustable and prolific. The plants therefore have the ability to adapt to altering environmental conditions such as soil water content. The pivotal reason is the very high costs associated with the conversion to varying application rates of seed. Bullock et al. (1998) found that varying application rates of seed holds little economic benefits for maize farmers, whilst English, Robberts \& Mahajanashetti (2003) found that there were only significant benefits if the soils in a land differ considerably.

Only $17 \%$ of the farmers apply herbicides at varying rates. Although the farmers consider the costs associated with the correct equipment too high, they are in principle willing to adopt this approach in order to save on pesticide application. Herbicide application rates are closely related to the texture of the soil, and with the fairly uniform clay contents of the soils in the study area. Thus, there appears to be no significant incentive to apply pesticides at variable rates.

\subsection{Costs associated with precision agriculture}

Costs to convert and implement precision agriculture can vary drastically between different companies as well as with the cultivation area. Table 3 presents estimated costs as calculated in 2017.

Table 3: Estimated costs for implementation of precision farming in 2017 (1 USD 12 ZAR)

\begin{tabular}{l|l}
\hline Component & Cost \\
\hline \hline Physical mapping & $\mathrm{R} 195 \mathrm{ha}^{-1}$ \\
\hline Chemical mapping & $\mathrm{R} 195 \mathrm{ha}^{-1}$ \\
\hline Lime distributor + hydraulic motor & $\mathrm{R} 202500$ \\
\hline Fertilizer planter (2 fertilizers) + hydraulic motor & $\mathrm{R} 225000$ \\
\hline Fertilizer planter (2 fertilizers) + hydraulic motor & $\mathrm{R} 262500$ \\
\hline Control computer with screen & $\mathrm{R} 64500$ \\
\hline Software & $\mathrm{R} 18000$ \\
\hline Base station for GPS & $\mathrm{R} 63000$ \\
\hline RTK signal & $\mathrm{R} 52500$ \\
\hline Automatic steering for tractor & $\mathrm{R} 120000$ \\
\hline
\end{tabular}

Physical mapping is a once-off expense, permitted that it is done right the first time. It is important that the same company is used for physical and chemical mapping to standardise any errors in the recommendations. The costs in Table 3 can be phased in over a number of years (hence the costs are expressed per hectare). A great number (44\%) of farmers in this study further reduced costs by converting existing implements instead of buying new ones. Worth noting was that not one of the farmers who adopted precision agriculture had to buy new 
S. Afr. J. Agric. Ext.

Vol. 46, No. 2, 2018: 107 - 118

DOI: http://dx.doi.org/10.17159/2413-3221/2018/v46n2a484

harvesters or tractors. Computers and associated software (as well as yield monitors) was simply installed on existing equipment.

All the farmers who adopted precision agriculture techniques agreed that it made economic sense and expenses incurred were recompensed within two years; for some within a year. Based on Figure 2c and Table 3, it appears that the area under cultivation has a significant impact on the adoption of precision agriculture. The economy of scale is certainly applicable and the cost per hectare decreases significantly with an increase in area under consideration. The cost associated with conversion to precision agriculture was by far the greatest factor limiting adoption of this technology in the study area (Table 4).

Table 4: Factors limiting adoption of precision agriculture technologies

\begin{tabular}{l|c|c}
\hline Factor & PA (\%) & Not PA (\%) \\
\hline \hline Costs & 55.6 & 66.7 \\
\hline Technology (computer literacy) & 16.7 & 0 \\
\hline Fear of change & 16.7 & 0 \\
\hline Lack of support & 5.6 & 0 \\
\hline Questions yield improvement & 5.6 & 0 \\
\hline Fields are relatively uniform & 0 & 11.1 \\
\hline Unavailability of financing & 0 & 5.6 \\
\hline Management issues & 16.7 & 5.6 \\
\hline Believe it is not worth the effort & 0 & 5.6 \\
\hline Rented fields & 0 & 5.6 \\
\hline Cultivated area is too small & 0 & 11.1 \\
\hline
\end{tabular}

Farmers who adopted precision agriculture believe that some of the important factors limiting adoption is 'fear of change' as well as lack of management skills and computer literacy. The majority of farmers in this study who have not adopted precision agriculture are however computer literate and $61 \%$ of them are considering converting to precision agriculture. The discrepancy in reasons given by the farmers who have adopted and those who did not for the lack of adoption is noteworthy. The farmers who have adopted precision agriculture consider sociological issues, such as 'fear of change' and 'management issues' as important limitations to conversion. The farmers who did not adopt precision agriculture attribute their decision mostly on physical issues such as costs as well as small and uniform fields (Table 4).

\subsection{Precision agriculture versus sustainable agriculture}

It appears that farmers practising precision agriculture are more sensitive to conservation than those who do not (Figure 4). Wind erosion is a specifically severe problem in the study area, however, mulching reduces wind erosion and evaporation whilst improving infiltration. 


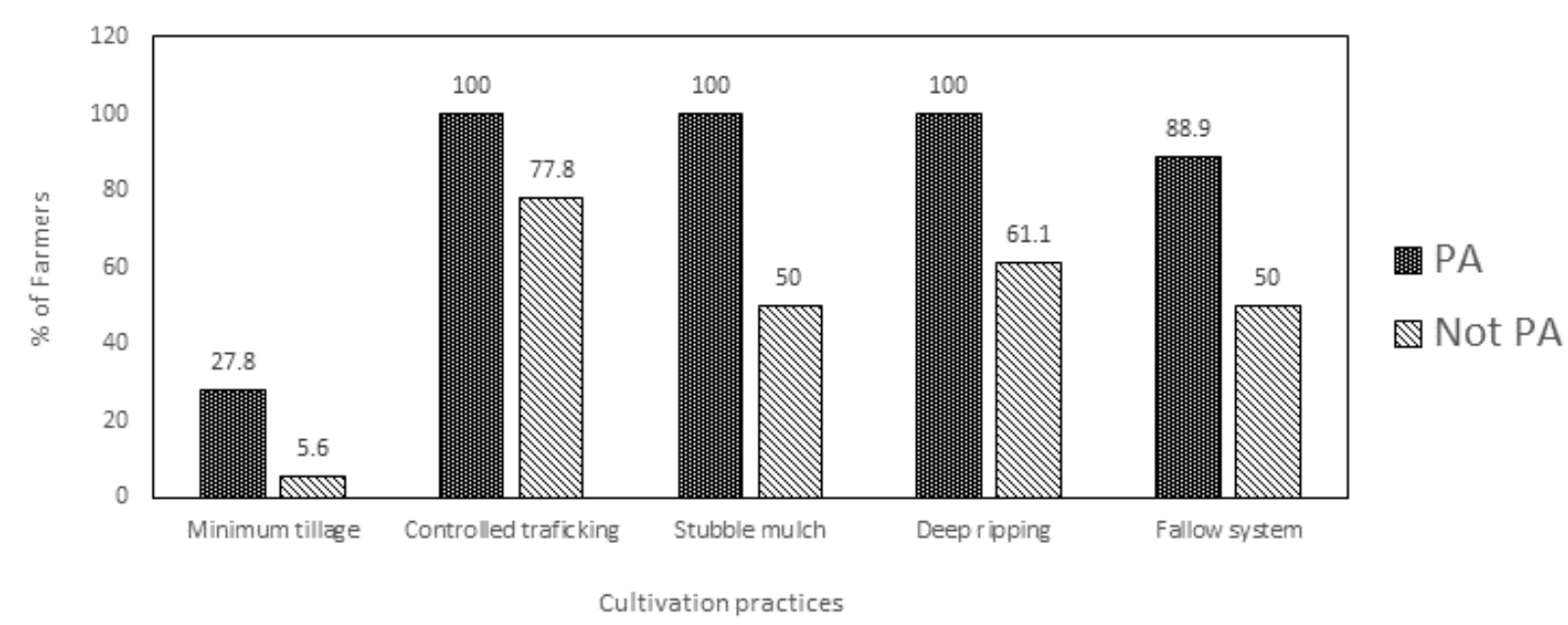

Figure 4: Percentage of farmers practising different conservation techniques.

PA refers to farmers practising precision agriculture and Not PA refers to the farmers who do not.

Minimum tillage, controlled trafficking and deep ripping are practiced reducing the risk of compaction on the sandy soils in the study area. According to the FSSA Fertilizer Handbook (2007), yields can be increased by up to $30 \%$ when deep ripping is conducted in combination with controlled trafficking. Conservation agriculture can further save energy and labour costs (Lal, Eckert, Fausey \& Edwards, 1990). The issue of size of cultivated area was a major consideration on whether farmers would let a land lie fallow. Farmers are not practising precision agriculture and are not making use of fallow systems since it would not be economically viable on their small fields. Fallow systems not only improve water conservation but also reduce the risk of amassing of pests in the soils.

In terms of soil fertility, most farmers (94\%) who adopted precision agriculture agreed that problem areas in their fields were adequately addressed. Of these, $89 \%$ believe that although they are not adding less fertilizers, the efficiency of the applications improved, whereas $83 \%$ of them stated that they are adding less lime. Most of them (94\%) feel that nutrient deficiencies in the soils are addressed better and all of them (100\%) agreed that both the yield potential and actual yields increased significantly (between 0.5 and 2.5 t. ha ${ }^{-1}$ ).

In addition, only $6 \%$ of the farmers who adopted precision agriculture reduced their labour force, while $83 \%$ indicated that their labourers required additional skills and had to be trained. Furthermore, $56 \%$ of the farmers are now paying skilled labourers more than what they used to and $89 \%$ of them indicated that the work hours did not decrease.

It is therefore clear that the farmers practicing precision agriculture are of the opinion that this practice is improving productivity, lowering production risks, reducing environmental degradation, improving economic viability, and (based on the potential advantages for labourers) is socially acceptable. According to these farmers, precision agriculture is therefore synonymous with sustainable agriculture.

\subsection{Potential improvements to the precision agricultural system}

A third of the farmers who are practising precision agriculture feel that the current system is working well, and that no significant improvements could be made. Only $39 \%$ of the 
S. Afr. J. Agric. Ext.

Vol. 46, No. 2, 2018: 107 - 118

DOI: http://dx.doi.org/10.17159/2413-3221/2018/v46n2a484

interviewees were however satisfied with the user-friendliness of the system. Improvements suggested by the farmers include:

- Thorough advice by extension service workers to farmers on operational aspects of precision agriculture.

- More uniformity between agricultural organisations on how to amend nutrient deficiencies.

- Servicing of equipment and conversion of equipment can be improved; suggestions for one-stop service centre for all precision farming needs.

- More technical advisors are needed. These advisors are extremely busy during the preplant and plant season and cannot visit and advise all the farmers.

- Applications of N, P and K should be conducted with electrical motors and not a gearbox.

- Computer software should be simplified and translated to the farmers' first language, namely Afrikaans.

- There must be continuous progress in precision farming with reference to equipment and software.

- Training programmes/ courses for labourers.

- More research on optimum levels of different nutrients in different areas are required.

- Theoretical predictions of yield potentials can be improved upon. This should include estimations based on topography, antecedent water contents conditions, etc.

These suggestions should be considered as direct needs of the farmers, and hence not be taken lightly by agricultural organisations, consultants and academics.

\section{CONCLUSION}

The study revealed that a farming's scale of economy is the most important determinant whether precision agriculture is adopted or not by crop farmers in the Schweizer-Reneke region. It is further noteworthy that neither the age nor the education of the farmers played a major role in the adoption or not of precision agriculture. The farmers who adopted precision agriculture claimed that the most beneficial outcome is the costs saved with variable fertilizer application. Despite the fact that these farmers are generally satisfied with the support to practice precision agriculture, they would like a one-stop service for equipment used and userfriendly computer programmes. The results of this study should be verified before extrapolation to other cropping regions.

\section{REFERENCES}

AGRICULTURAL RESEARCH COUNCIL - INSTITUTE FOR SOIL, CLIMATE AND WATER (ARC-ISCW). 2017. AgroClimatology Staff, Pretoria. 
S. Afr. J. Agric. Ext.

Vol. 46, No. 2, 2018: 107 - 118

DOI: http://dx.doi.org/10.17159/2413-3221/2018/v46n2a484
Jacobs, Van Tol \&

Du Preez.

(License: CC BY 4.0)

BABCOCK, B. A. \& PAUTSCH, G. R. 1998. Moving from uniform to variable fertilizer rates on Iowa corn: Effects on rates and returns. Journal of Agricultural and Resource Economics., 23:385-400.

BIERMAN, C. R. 2001. Grondvrugbaarheid en bemesting in die Noordwesprovinsie met verwysing na volhoubare droëlandgewasverbouing (In Afrikaans). Unpublished M.SA minor dissertation, University of the Free State, Bloemfontein, South Africa.

BULLOCK, D. G., BULLOCK, E. D., NAFZIGER, E. D., DOERGE, T., PASZKIEWICS, S., CARTER, P. \& PETERSON, T. A. 1998. Does variable rate seeding of corn pay? University of Illinois, Urbana, USA.

CLAY, D. E., MALO, D. D., REESE, C. \& CARLSON, C. G. 2003. Identifying good candidates for precision phosphorous management. Site specific management guideline 13. College of Agriculture and Biological Sciences, South Dakota State University, USA.

ENGLISH, C. B., ROBBERTS, R. K. \& MAHAJANASHETTI, S. B. 2003. Spatial break-even variability of variable rate technology adoption. Department of Agricultural Economics, University of Tennessee, Knoxville, USA.

FSSA FERTILIZER HANDBOOK. 2007. The Fertilizer Society of South Africa, Lynwood Ridge, Pretoria, South Africa.

GODWIN, R. J., EARL, R., TAYLOR, J. C., WOOD, G. A., BRADLEY, R. I., WELSH, J. P., RICHARDS, T., BLACKMORE, B. S., CARVER, M. J., KNIGHT, S. \& WELTI, B. 2002. Precision farming of cereal crops: A five-year experiment to develop management guidelines. HGCA Project Report 267, London.

HELM, C. 2005. Precision farming in South Africa. Farm Technology Proceedings., 76-80.

IUSS WORKING GROUP WRB. 2014. World reference base for soil resources 2014. World Soil Resources Reports No. 106, FAO, Rome, Italy.

KAHABKA, J. E., VAN ELS, H. M., MCCLENAHAN, E. J. \& COX, W. J. 2004. Spatial analysis of maize response to $\mathrm{N}$ fertilizer in central New York. Precision Agriculture., 5:463-476.

LAL, R., ECKERT, D. J., FAUSEY, N. R. \& EDWARDS, W. M. 1990. Conservation tillage in sustainable agriculture. In: Edwards, C. A., Lal, R., Madden, P., Miller, R. H. \& House, G (eds). Sustainable Agriculture Systems. Soil and Water Conservation Society, Iowa, USA. pp. $203-222$.

LEEDY, P. D. \& ORMAND, J. E. 2005. Qualitative research methodologies. In: Practical research; Planning and design $8^{\text {th }}$ edn. Pearson Education International, New York, USA.

LE ROUX, P. A. L., ELLIS, F., MERRYWEATHER, F., SCHOEMAN, J. L., SNYMAN, K., VAN DEVENTER, P. W. \& VERSTER, E. 1999. Guidelines for the mapping and interpretation of soils in South Africa. University of the Free State, Bloemfontein, South Africa.

MAINE, N. 2006. The profitability of precision agriculture in the Bothaville district. Unpublished M.Sc. dissertation. University of the Free State, Bloemfontein, South Africa.

MATELA, N. 2002. The status of precision agriculture in South Africa. Unpublished M.Sc. dissertation. University of the Free State, Bloemfontein, South Africa.

NATIONAL RESEARCH COUNCIL (NRC). 1997. Precision agriculture in the $21^{\text {st }}$ century. National Academy Press. Washington, D.C.

NELL, W. T., MAINE, N. \& BASSON, P. M. 2006. Africa. In Handbook of precision agriculture. Srinivasan (ed). The Haworth Press, Inc.

PARKHOMENKO, P., ROBERT, P., ROGASIK, J. \& SCHNUG, E. 1999. Profitability of precision agriculture: A case study from Germany. Federal Agricultural Research Institute (FAL), Braunschweig, Germany and Department of Soil, Water and Climate, University of Minnesota, USA. 
S. Afr. J. Agric. Ext.

Vol. 46, No. 2, 2018: 107 - 118

DOI: http://dx.doi.org/10.17159/2413-3221/2018/v46n2a484
Jacobs, Van Tol \&

Du Preez.

(License: CC BY 4.0)

PIERCE, F. J. \& NOWAK, P. 1999. Aspects of precision agriculture. Advances in Agronomy., 67:1-85.

SMYTH, A. J. \& DUMANSKI, J. 1995. A framework for evaluating sustainable land management. Canadian Journal of Soil Science., 75:401-406.

SOIL CLASSIFICATION WORKING GROUP. 1991. Soil classification - A taxonomic system for South Africa. Department of Agricultural Development, Pretoria, South Africa.

SRINIVASAN, A. 2006. Precision agriculture: An overview. In Handbook of precision agriculture. Srinivasan (ed). Haworth Press, Inc.

ZHANG, H. 2001. Seeking dialogue between two research paradigms: Use of quantitative measures to supplement a qualitative study. Post-Script. 2:91-114. 